\title{
IDENTIFICATION OF VEGETATION COVERAGE SEASONS IN IRAN USING ENHANCED VEGETATION INDEX (EVI)
}

\author{
SOBHANi, B. ${ }^{*}$ - ABAD, B. - KefAYAT MotLAGH, O. M. \\ Department of Natural Geography, University of Mohaghegh Ardabili, Ardabil, Iran \\ *Corresponding author \\ e-mail: sobhani@uma.ac.ir; phone: +98-091-4152-9568; fax: +98-045-3351-6402
}

(Received $12^{\text {th }}$ Feb 2018; accepted $17^{\text {th }}$ May 2018)

\begin{abstract}
Vegetation coverage seasons are affected by climatic elements and changes in climatic elements influence the vegetation growth period. The purpose of this research is to identify the vegetation coverage seasons of Iran, with the help of the Enhanced Vegetation Index (EVI). In this research, 16-day data of Iran's Enhanced Vegetation Index (EVI) was downloaded from MODIS Aqua website from July 14, 2002 to March 14, 2015. Then, on the basis of nearly 10 billion cells, the long-term mean of the 16day EVI was calculated, and a time-location array was obtained at a dimension of $23 * 7541502$. The results of cluster analysis on the Euclidean distances of this array were investigated by Ward method. This study shows that according to the local pattern of EVI in Iran, there are three different seasons, including a massive/dense season (from the April $14^{\text {th }}$ to the June $1^{\text {st }}$ ) that the highest density is in the north and west of Iran, a transition season (from the June $17^{\text {th }}$ to the October $7^{\text {th }}$ ) that the highest compression on the Caspian Sea coast, and less severity along the Alborz heights, and the season of thinning (from the October $23^{\text {rd }}$ to the March $29^{\text {th }}$ ), the highest density of which is along the coast of the Caspian Sea, on the Khuzestan plain, and also in the southern half of the country.
\end{abstract}

Keywords: vegetation, cluster analysis, EVI, MODIS, Iran

\section{Introduction}

The MODIS sensor provides comprehensive information on the surface of the Earth, the Oceans, and the Atmosphere in a variety of different spectrums (Babu et al., 2016). By using the data of the MODIS, better maps of the vegetation coverage of the Earth can be provided. With these maps, estimates of the distribution of different types of vegetation coverage at ground level would be obtained (Mumtaz et al., 2017). Changes of vegetation coverage that occur during a year through different seasons, can be used as a factor for the interpretation of vegetation coverage maps (Di Vittorio and Georgakakos, 2018). In fact, the growing seasons show the growth conditions of different types of vegetation coverages throughout the year (Yang et al., 2017). The growing seasons are the most affected by the climate (Tsalyuk et al., 2017; Moriondo and Bindi, 2007) which determine the start and termination of the climate systems of the beginning and end of the growing seasons (Testa et al., 2018). In a study the relationship of vegetation coverage changes between the border of the desert of Africa and the West of Africa, which is known to have a minor effect on the monsoon cycle, was investigated (Zheng and Eltahir, 1998; Zhang et al., 2015); therefore, the coastal deforestation may be the cause of the disappearance of the monsoon, and have a great effect on the precipitation of the area (Ardo et al., 2018). According to research Ratana et al. (2005), the vegetation coverage index in Korado shows a high seasonal contradiction in the dry season between June and August, and the wet season between November and March; and also Muhammad et al. (2016) and Shi et al. (2017) have classified important products and vegetation coverage based on the Enhanced Vegetation Index (EVI) and images from the MODIS sensor. 
Erasmi et al. (2009) investigated the reduction of forage productivity, a 10-day combination index of the normalized vegetation coverage, that was used for imaging (and measuring) the 250-meter resolution of the MODIS sensor. In a study, using MODIS sensor data to rebuild the vegetation coverage dynamics, in response to climate patterns for the period 2001-2005 was used for North America. In a study by Cabello et al. (2012), the regional and spatial responses of the enhanced vegetation coverage profile are attributed to environmental factors, but in the dry regions of the Southeast of Spain on an annual scale is reviewed, and the effect of climate on this index has been revealed (Villani et al., 2011; Knezevic et al., 2017). The research results of Lorenz et al. (2013) show that vegetation coverage phenology has a limited effect on the mean of European summer climate (Hilker et al., 2015). The results of Jamali et al. (2011) showed that NDVI and EVI are highly correlated with soil moisture at all sites up to a 1 $m$ depth implying strong relationships between vegetation growth and soil moisture at these depths, where most of the root biomass is located. Furthermore, EVI shows slightly higher correlations with soil moisture than NDVI at all sites during the growing season. In addition, EVI responds to soil moisture changes earlier than NDVI by about 0-4 days at the sub-Saharan sites where rainfall is a controlling factor. These slightly stronger relationships with EVI might occur because of improved corrections for variations in atmosphere, soil, and canopy background which make it sufficient for monitoring open canopy areas such as grasslands and savannas (Huete et al., 1997). Based on Peng et al. (2017) the effects of rainfall on vegetation coverage vary according to the rainfall time and the type of growing form, so that in urban areas, there is no significant relationship between the amount of precipitation and the vegetation coverage, in any time scale. In pasture lands, the strongest correlation is observed between the spring rainfall and the vegetation coverage changes, while the forest area shows the strongest correlation with annual precipitation (Pisek et al., 2015), and the strongest correlation with rainfall in spring and March is seen in the arable land (Allen et al., 2010), In the meadow areas, there is also a stronger correlation between rainfall and bushes (Son et al., 2014). Regarding the identification and classification of changes in the plant growth index (EVI) by MODIS sensor in Jiangxi province of China (Zhang et al., 2014; and Raghavendra and Aslam, 2017), in Karnatkay of India, in the southern part of Vietnam, and in Uttar Pradesh of India some research studies were done (Bansal et al., 2017). Since the vegetation coverage seasons show the condition of the vegetation coverage compression of an area throughout the year, and also its effect on the life of plant and animal ecosystems, the purpose of this study is to identify the seasons of Iran's vegetation coverage, based on the enhanced vegetation index (EVI) by using the MODIS Aqua sensor.

\section{Data and Methods}

In this research, the data of MODIS Aqua sensor were used for dividing the vegetation coverage into seasons in Iran. The MODIS Aqua sensor was launched on the June $4^{\text {th }}, 2002$ by NASA (Vermote et al., 2002). The time the satellite passed over the equator was 13:30 local time (Wang and Xie., 2009). To find the seasonal vegetation coverage of Iran, at first, the 16-day data of the Enhanced (Growth of) Vegetation Index (EVI) of the MODIS-Aqua with a local resolution of 500 meters in the time interval from July 14, 2002 to March 14, 2015were extracted from the MODIS website, which covered the territory of Iran in 6 tiles. The dimensions of each tile was $3600 * 2400$ cells, 
and each square cell was 463.31 meters. Six tiles were said to be one mosaic, which means that there are 23 mosaics of 16 days throughout the year. Due to the fact that the used data also included the extraterritorial land of Iran, with the help of the in-polygon function of the MATLAB software, only the data that were covering the geographical intra-boundary of Iran were extracted. The long-term mean of vegetation coverage of Iran was calculated for every 16-days, that for each, an array of $7200 * 4800$ cells was obtained. These estimates are representative of the local behavior of vegetation coverage in every 16-days of the year, with the arrangement of a time-local array of dimensions of $23 * 75841502$. This array was the basis of our judgments for dividing the vegetation coverage into seasons in Iran.

EVI was developed to optimize the vegetation signal with improved sensitivity in high biomass regions and improved vegetation monitoring through a de-coupling of the canopy background signal and a reduction in atmosphere influences (Aulia et al., 2016; Ogilive et al., 2015).

$$
\mathrm{EVI}=\mathrm{G} \frac{N-R}{N+C_{1} R-C_{2} B+L}
$$

where N, R, and B are atmospherically corrected or partially atmosphere-corrected (Rayleigh and ozone absorption) surface reflectances in near-infrared, red and blue bands respectively; $\mathrm{G}$ is a gain factor; $\mathrm{C} 1, \mathrm{C} 2$ are the coefficients of the aerosol resistance term, which uses the blue band to correct for aerosol influences in the red band, and L functions as the soil-adjustment factor, attributed to the interaction and feedbacks between the soil-adjustment factor and the aerosol resistance term (Liu and Huete, 1995; Jiang et al., 2008). The coefficients adopted in the MODIS EVI algorithm are, $\mathrm{L}=1, \mathrm{C}_{1}=6, \mathrm{C}_{2}=7.5$, and $\mathrm{G}=2.5$. EVI has been used recently in a wide variety of studies, including those on land cover/land cover change (Wardlow et al., 2007), estimation of vegetation biophysical parameters (Chen et al., 2004; Houborg et al., 2007), phenology (Ahl et al., 2006; Zhang et al., 2003; Bolton and Friedl, 2013), evapotranspiration (Nagler et al., 2005; Nouri et al., 2016), biodiversity (Waring et al., 2006; Sloan et al., 2014), and the estimation of gross primary production (GPP) (Rahman et al., 2005; Zhang et al., 2014).

Accordingly, at first by calculating the Euclidean distance of the vegetation coverage of the entire local points of the array $\mathrm{k}$ before all the mosaics, we measure the dissimulated degree of the sites (Eq. 2).

$$
d_{r s}^{2}=\left(k_{r}-k_{s}\right)\left(k_{r}+k_{s}\right)^{\prime}
$$

$d_{r s}^{2}$ is the Euclidean distance of the point $r$ with the coordinates of $\left(\varphi_{r}, \lambda_{r}\right)$ and the point $s$ with the coordinates of $\left(\varphi_{r} \cdot \lambda_{r}\right)$ or the Euclidean distance of the $r$ group and the $s$ groups;

$k_{r}$ is the vegetation coverage of the $r$ spot or group;

$k_{s}$ is the vegetation coverage of the $s$ spot or group;

After measuring the Euclidean intervals, a cluster analysis was performed by Ward method into an array of distances (M), and the 75841502 point of the $k$ array was arranged together in accordance with the simulated degree (Fig. 2). 
In the method, the $\mathrm{R}$ and $\mathrm{S}$ groups are merged if the increase in the variance resulting from their integration is minimized relative to the integration of each of them with other groups (Eq. 3):

$$
d(x \cdot y)=\frac{n_{r}+n_{s}+n_{r s}^{2}}{\left(n_{r}+n_{s}\right)}
$$

Here $n_{r s}^{2}$ is the distance between the group $r$ and the group $s$, that are obtained by the central transplant method. $n_{r}$ is the number of members of the group $r$, and $n_{s}$ is the number of members of the group $s$. Based on this analysis, Iran has three seasonal vegetation coverages (Fig. 2). For a better understanding of the phenomena, the Iranian Digital Elevation Model (DEM) is depicted in 500-m location with a sine-image system (Fig. 3). By distinguishing the vegetation coverage of each of the $k$ array local spot, the map of seasonal vegetation coverage of Iran was drawn (Figures 4, 5, 6).

\section{Results and Discussion}

Figure 1 shows the Enhanced Vegetation Index (EVI). According to the definition of EVI the values between 1-0.8 represent a very dense vegetation cover, 0.8-0.6 represent dense cover, 0.6-0.4 stands for average cover, 0.4-0.2 correspond to sparse, 0.2-0 represent a poor and the background soil (Chakraborty et al., 2016). of course, a range of 0.1 indicates the background soil, and 0.2-0.1 can also indicate grasslands and bushes (Zhou et al., 2016), which are known as the soil in this research. The values of less than zero are also known as water resources, which may be lakes, wetlands, dams, snow, and even mountain ice (in the cold season). In general, in this study, the EVI values are considered to be more than 0.2 as vegetation covering.

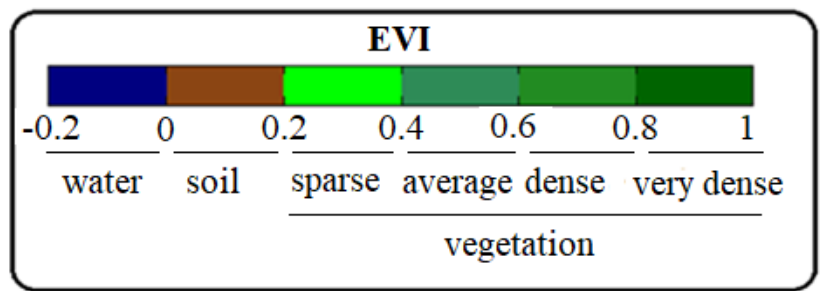

Figure 1. The Defined Values of EVI in this Research

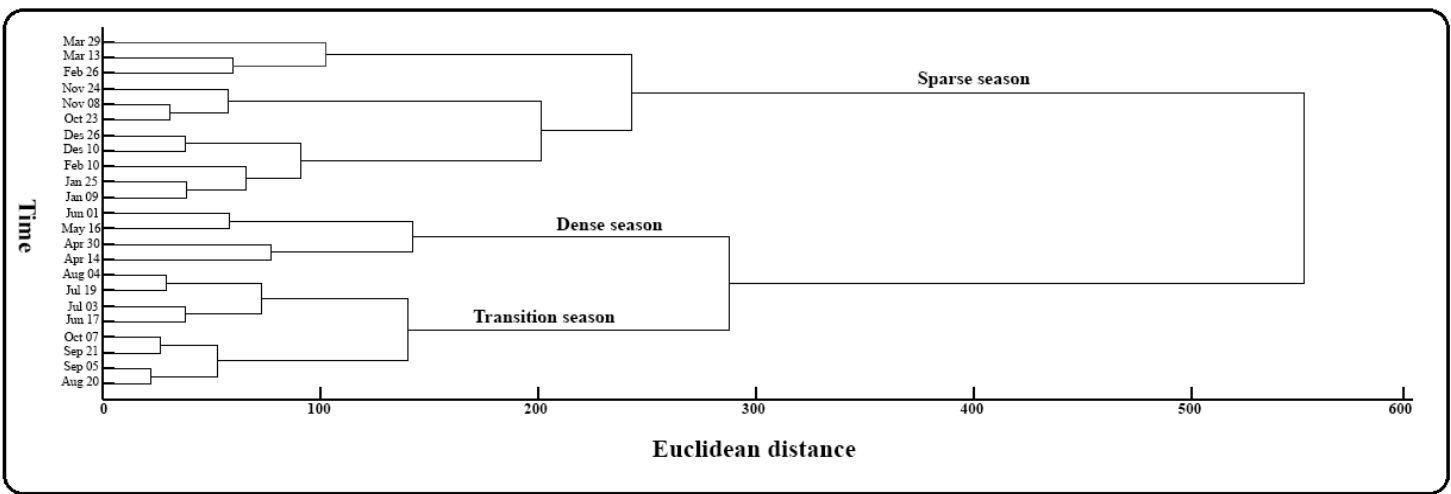

Figure 2. The Clustering of EVI by Ward method 


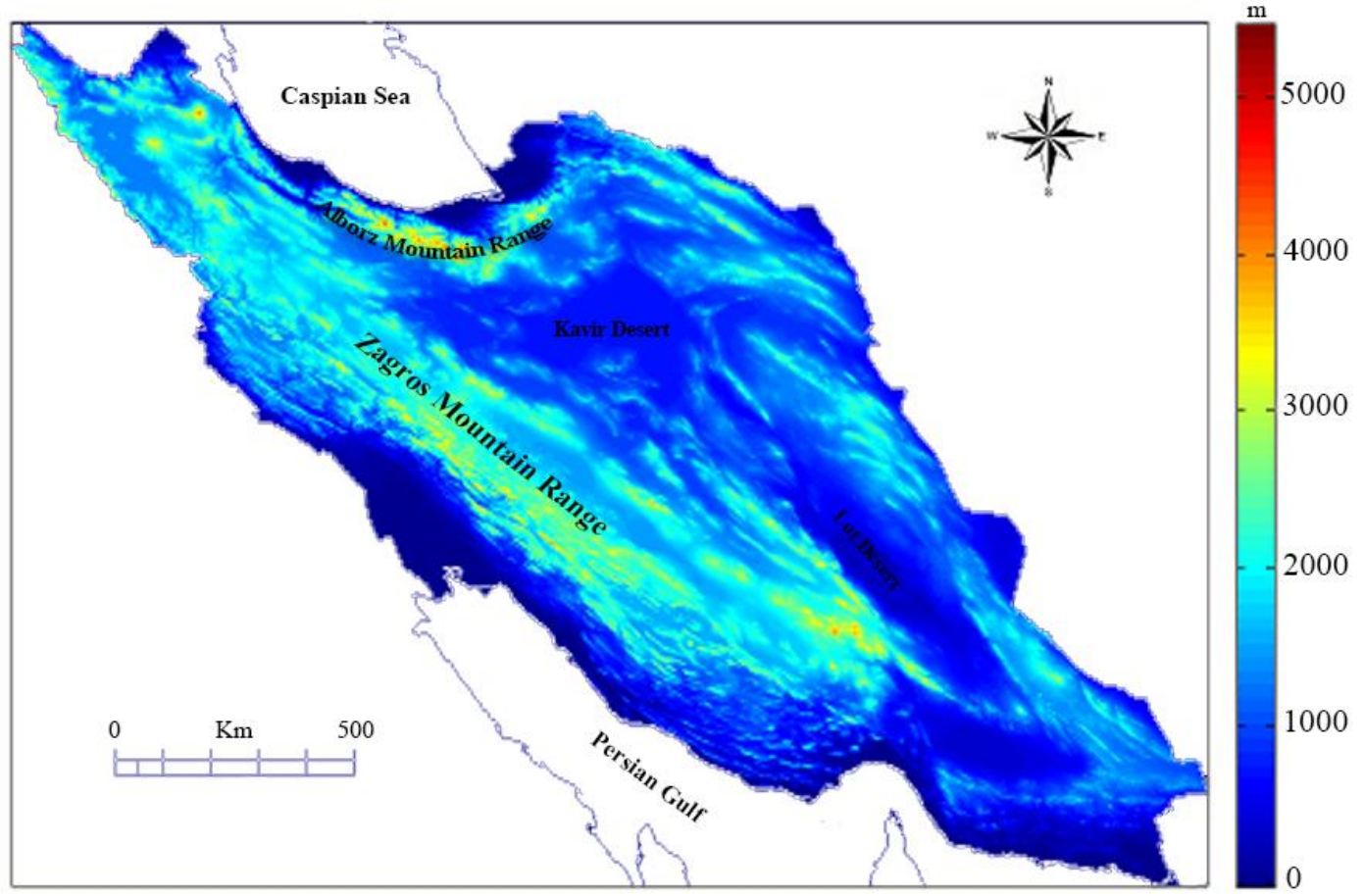

Figure 3. Digital Elevation Model of Iran in $500 \mathrm{~m}$ spatial resolution with a sine image system

By analyzing the clustering method, the country of Iran was divided into three dense, transition, and sparse seasons, regarding the vegetation coating, as shown in Figure 2.

\section{The Sparse Season}

Figure 4 shows the long-term mean of the vegetation coverage of the sparse season in the period from the October $23^{\text {rd }}$ to the March $29^{\text {th }}$. During this time period, the vegetation coverage is insignificant, so that only 2.5 percent of the country's coverage is covered, and this amount is also sparse. The highest density of vegetation coverage in the Northern half of the country was only seen along the coasts of the Caspian Sea, and in the Southern half of the country in the plain of Khuzestan, Bushehr, West of Kohgiluyeh and Boyerahmad, South of Fars and Kerman, North and Northeast of Hormozgan. The main cause of the most densely populated vegetation cover in the mentioned areas is temperate temperature and winter rainfall, while in other parts of the country, there is no plant in this time period due to the low temperature, snow and ice cover. In addition to the mentioned areas, in the central regions of Southern Tehran, Qom and the East of Isfahan, in the Western regions of Western Kermanshah, East of Ilam and West of Lorestan, in the East of the country in the West and South of Xorasan Razavi and North of the South Xorasan, and finally in the North of the country, in the North of Ardabil Province, in the plain of Moghan very weak and dotted areas of the sparse vegetation coverage were observed. Mean, dense, and very dense vegetation is not seen in any part of the country. Because of the low temperature, snow and rain, the area of snow, ice cover and water is maximum amounts, that cover about 1.3 percent of the country's coverage. Through the broad surface, in the Northern parts of China (Mao et al., 2014), the coasts of Africa (Fetzel et al., 2015), the North of America (Potter et 
al., 2008), and the coastline of the country Mali (Spiekermann et al., 2015) seasonal variations of temperature changes the plant's vegetation coverage. The blue color in the map shows from one side, the snow cover on the Alborz and Zagros heights and the peaks of Sabalan and Sahand, and on the other side, the waters of Urmia Lake and the lakes of Fars Province. About 96 percent of the country's land is covered by poor vegetation/soil cover.

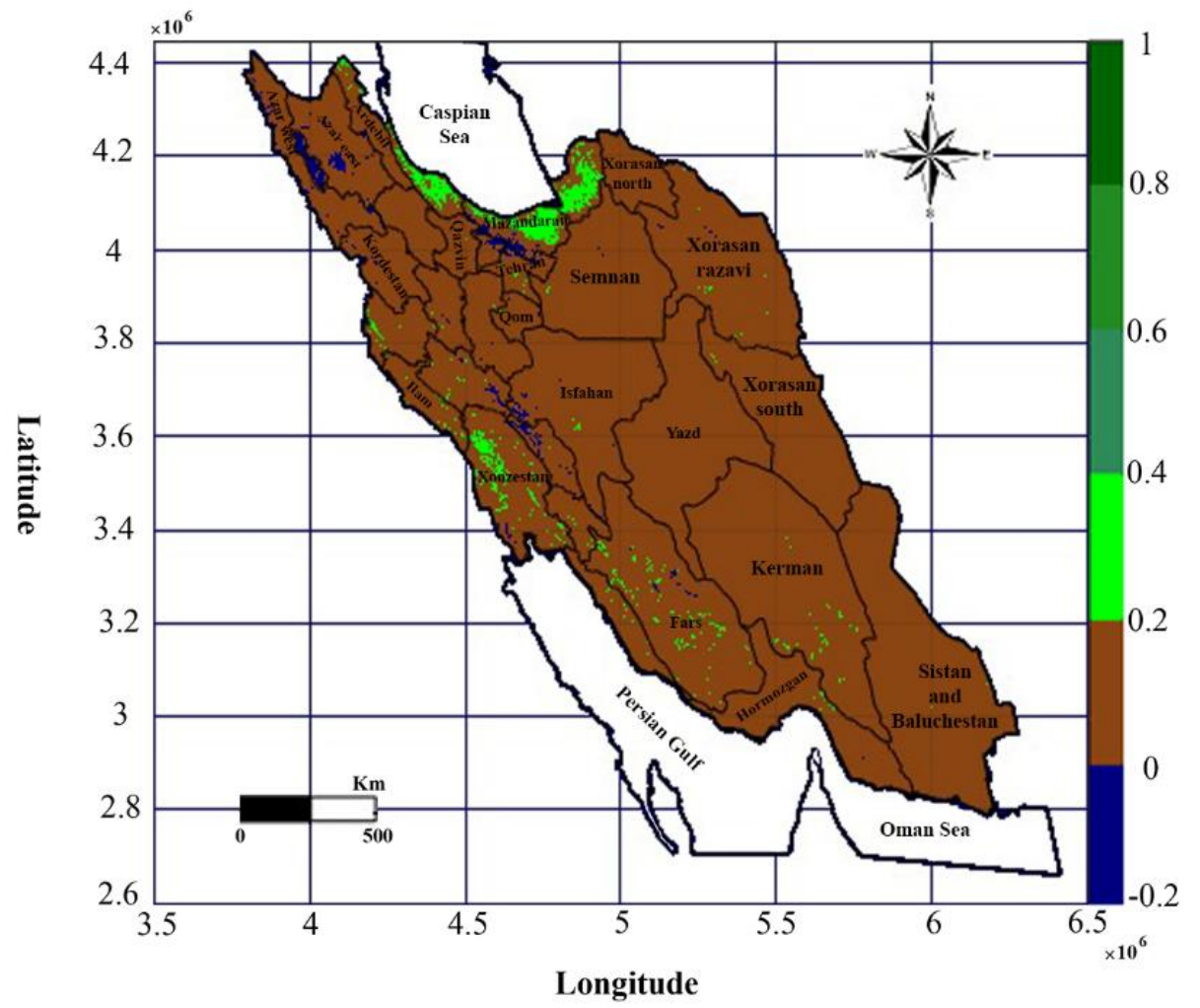

Figure 4. The Long-term mean Sparse season from October $23^{\text {rd }}$ to March $29^{\text {th }}$

\section{The Dense Season}

Figure 5 shows the long-term mean of vegetation coverage of the dense season in the period from the April $14^{\text {th }}$ to the June $1^{\text {st }}$ when the vegetation coverage growth is at its peak. In this period, the sparse vegetation coverage is still very wide and covers about 12.5 percent of the country, its highest density was observed in the Western half of the country, along the Zagros mountains and throughout the Northern half of the country, and even the Northeast of the country. The mean vegetation coverage in this interval is at its maximum amount, and covers about 1.5 percent of the country. The highest density of the mean vegetation coverage was observed along the coasts of the Caspian Sea; in addition to this area, it was observed in the Northwest of the country in the provinces of West Azerbaijan, and also the Sahand slopes in Azar East and the Sabalan slopes in Ardabil and in the Western provinces of the country, the provinces of Kermanshah, Hamedan and Lorestan, also in the provinces of Chaharmahal and Bakhtiari and Kohgiluyeh and Boyer Ahmad in the Southern half of the country. Also, in the mountains of Southern Alborz slope and central regions of the provinces of Fars and Kerman, there is the mean vegetation coverage, spottedly. In this period of time, 
since it is at its peak of growing, there is also a dense vegetation covering about 1480 square kilometers of the country that only was observed by the Caspian Sea, especially by its Southern coast. The soil surface has declined due to the significant increase in vegetation coverage over this time period, and covers about 85.4 percent of the country. The coverage of snow, ice, and water involves about 0.4 percent of the country. The color blue on the map, in this period, shows the other water resources and rivers of the country, such as the lakes of Fars Province, Shadegan wetland in Khuzestan, Hirmand River in Sistan and Baluchestan, Zayandehrud in Isfahan, as well as rivers along the Alborz and Zagros heights. At this time, the extent of the snow and ice cover is very small, and can only be spotted in the Alborz and Zagros heights. In general, during the dense season 14.14 percent of the country is covered by vegetation including sparse, transition, and dense. Even in this season, where vegetation is maximized, there is no massive vegetation, and it shows the poor vegetation of Iran.

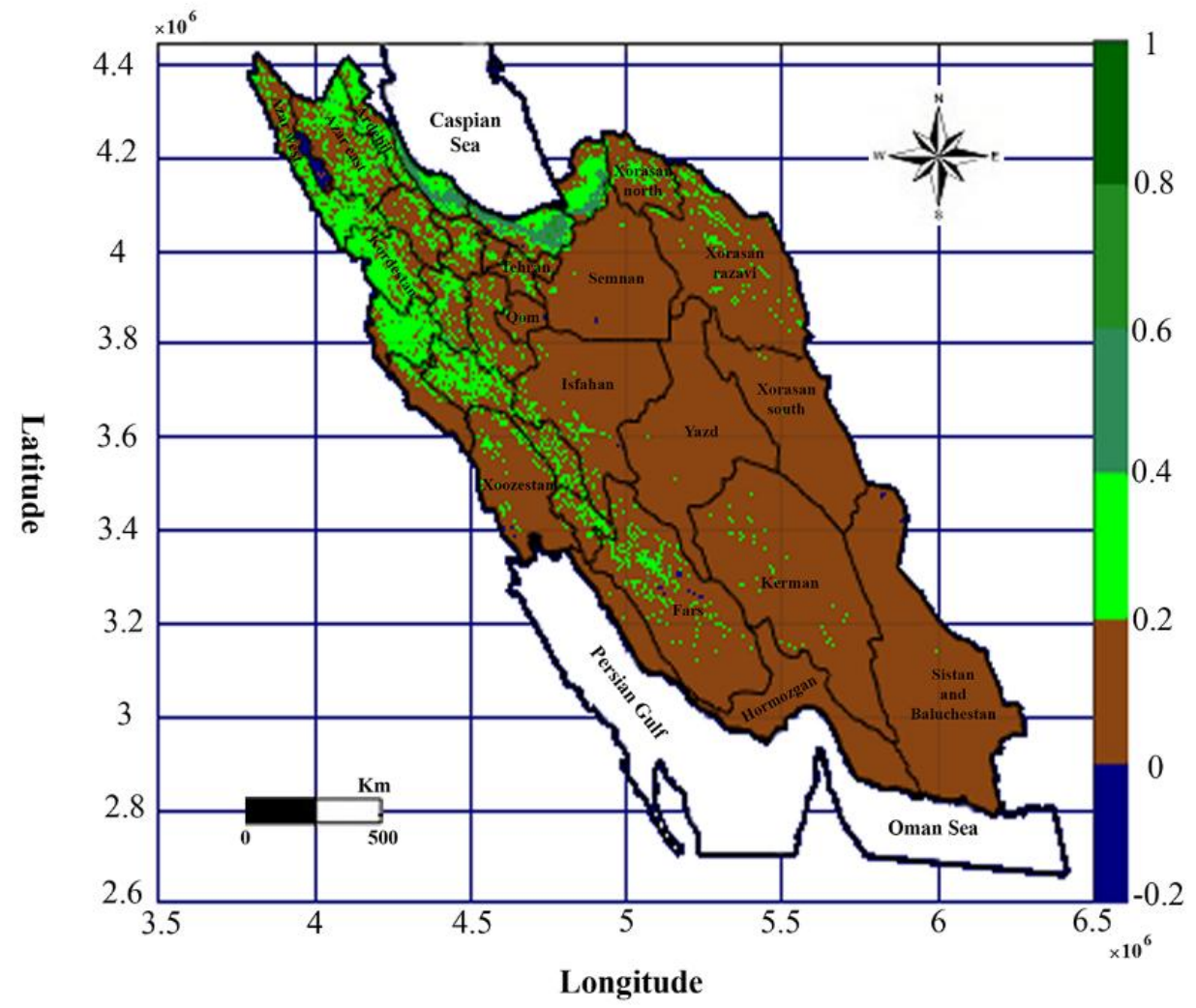

Figure 5. The Long-term mean Dense season from April $14^{\text {th }}$ to June $1^{\text {st }}$

\section{The Transition Season}

Figure 6 indicates the long-term mean vegetation coverage of the transition season in the period from the June $17^{\text {th }}$ to October $7^{\text {th }}$, which is exactly in the warm period of the year. During this period, the sparse vegetation coverage, which is sporadic in most parts of the country except the central and Eastern deserts of the Southeast, it covers about 3.8 percent of the country's territory. By looking at the map, it can be seen clearly that the sparse vegetation coverage, except the Caspian shores, in other parts of the country almost everywhere is consistent with the high altitudes of the country, so that in the Northern half of the country, this vegetation coating along the Alborz highlands, in the 
Western half of the corresponding of the Zagros heights and in the North-East of the country, which is in line with the altitudes of Xorasan. In addition to the mentioned areas, in the southern regions of the country, the sparse vegetation coverage in this interval is almost in line with the high altitudes, so that the existense of the vegetation coverage of Zagros, in the range of Kohgiluyeh and Boyer Ahmad provinces, Chaharmahal and Bakhtiari and Fars, as well as in the desert provinces of Kerman and Yazd, on the highlands of Laleh Zar and Shirkooh, are well known. The reason for the presence of denser vegetation coverage on the heights compared to the plain areas in this time interval on the one hand can be attributed to the presence of adequate amount of water, on the other hand to the proper temperature, which helps the growing of vegetation cover. In addition to the above altitudes, there is also the presence of sparse vegetation coverage along Zayandehrud and Khuzestan plain. The mean vegetation coverage covers about 1.2 percent of the country and its highest density is along the coasts of the Caspian Sea due to its favorable rainfall and temperate temperature in this area during this time period for vegetation cover. After the coasts of the Caspian Sea in the North and West of the country, the mean vegetation coverage is significant in the province of the East Azarbayjan, in the Sahand slopes along the Aras river in the North of this province, and in the Azar West Province, in the West of the Urmia Lake. In addition to the mentioned areas, the average vegetation cover is also found in limited areas in the southern Alborz and the central and northern heights of the Zagros Mountains. The dense and very dense vegetation coatings at this time, are not visible at any point in the country. The water content is also 0.34 percent. At this time of year, the amount of soil is significant and covers about 94.5 percent of the country's total area.

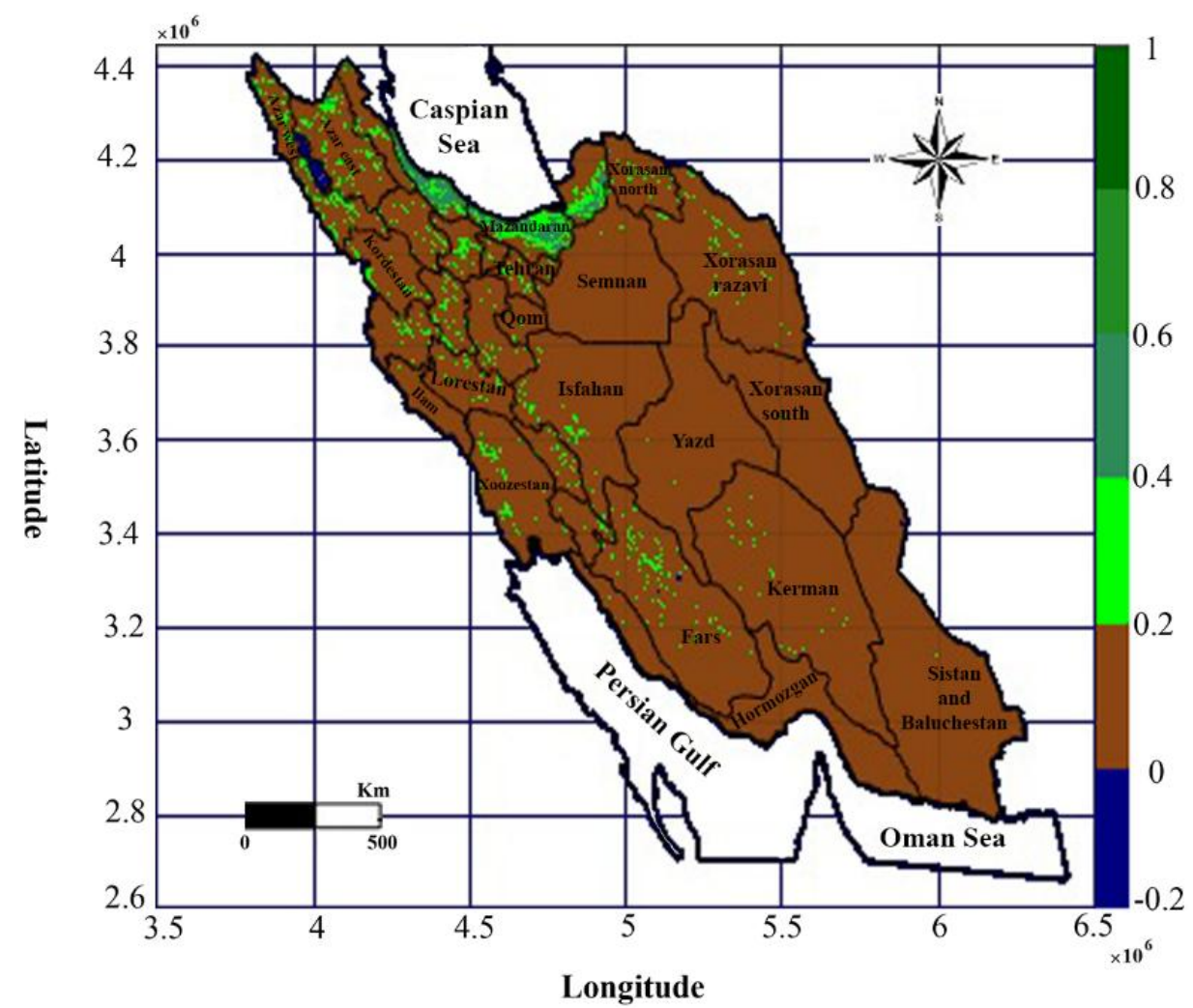

Figure 6. The Long-term mean Transition season from June $17^{\text {th }}$ to October $7^{\text {th }}$ 


\section{Conclusion}

The vegetation coverage changes that occur during a year through different seasons, can be used as a factor in the interpretation of vegetation coverage maps. The purpose of vegetation coverage indices is to predict and evaluate some of the characteristics of the vegetation coating, such as the crown covering, biomass, leaf spread, or the percentage of vegetation coating. In this study, initially, from the total of 23 maps of the 13-years long-term mean period was taken, and in the next step a cluster analysis was carried out resulting in the creation of clusters of maps that are similar to each other. Then, it was classified into Iran's growing seasons by the Ward method; Iran has three vegetation (and growing) seasons over the year; the first season has a dense vegetation coating, and its period is from the April $14^{\text {th }}$ to the June $1^{\text {st }}$. In this season, about 14 percent of Iran's area, due to the temperature and precipitation adjustments, is covered by plants. Its highest density is seen in the Zagros, Alborz, Northeastern highlands and along the coasts of the Caspian Sea. In the second season, the vegetation coverage is in the transitional stage, and covers the period from the June $17^{\text {th }}$ to October $7^{\text {th }}$, and its highest density is observed along the coasts of the Caspian Sea and the highlands of Alborz and Zagros. The third season has a sparse vegetation covering, and its period is from the October $23^{\text {rd }}$ to March $29^{\text {th }}$, and due to the coldness of the air in most parts of the country, only 2.5 percent of Iran's territory is covered. Its highest density is along the coasts of the Caspian Sea, Khuzestan plain, and Southern half of the country. For future studies, it is recommended to compare vegetation indices such as EVI and NDVI in the study area.

\section{REFERENCES}

[1] Ahl, D. E., Gower, S. T., Burrows, S. N., Shabanov, N. V., Myneni, R. B., Knyazikhin, Y. (2006): Monitoring spring canopy phenology of a deciduous broadleaf forest using MODIS. - Remote Sensing of Environment 104(1):88-95.

[2] Allen, T. L., Curtis, S., Gamble, D. W. (2010): The midsummer dry spell's impact on vegetation in Jamaica. - Journal of Applied Meteorology and Climatology 49(7):15901595.

[3] Ardö, J., Tagesson, T., Jamali, S., Khatir, A. (2018): MODIS EVI-based net primary production in the Sahel 2000-2014. - International Journal of Applied Earth Observation and Geoinformation 65:35-45.

[4] Aulia, M. R., Setiawan, Y., Fatikhunnada, A. (2016): Drought Detection of West Java's Paddy Field Using MODIS EVI Satellite Images (Case Study: Rancaekek and Rancaekek Wetan). - Procedia Environmental Sciences 33:646-653.

[5] Babu, M. J., Geetha, P., Soman, K. P. (2016): MODIS-Aqua Data Based Detection and Classification of Algal Blooms along the Coast of India Using RLS Classifier. - Procedia Computer Science 93:424-430.

[6] Bansal, S., Katyal, D., Garg, J. K. (2017): A novel strategy for wetland area extraction using multispectral MODIS data. - Remote Sensing of Environment 200:183-205.

[7] Bolton, D. K., Friedl, M. A. (2013): Forecasting crop yield using remotely sensed vegetation indices and crop phenology metrics. - Agricultural and Forest Meteorology 173:74-84.

[8] Cabello, J., Alcaraz-Segura, D., Ferrero, R., Castro, A. J., Liras, E. (2012): The role of vegetation and lithology in the spatial and inter-annual response of EVI to climate in drylands of Southeastern Spain. - Journal of Arid Environments 79:76-83. 
[9] Chakraborty, K., Gupta, A., Lotliker, A. A., Tilstone, G. (2016): Evaluation of model simulated and MODIS-aqua retrieved sea surface chlorophyll in the eastern Arabian Sea. - Estuarine, Coastal and Shelf Science 181:61-69.

[10] Chen, X., Vierling, L., Rowell, E., DeFelice, T. (2004): Using lidar and effective LAI data to evaluate IKONOS and Landsat 7 ETM+ vegetation cover estimates in a ponderosa pine forest. - Remote Sensing of Environment 91(1):14-26.

[11] Di Vittorio, C. A., Georgakakos, A. P. (2018): Land cover classification and wetland inundation mapping using MODIS. - Remote Sensing of Environment 204:1-17.

[12] Erasmi, S., Propastin, P., Kappas, M., Panferov, O. (2009): Spatial patterns of NDVI variation over Indonesia and their relationship to ENSO warm events during the period 1982-2006. - Journal of Climate 22(24):6612-6623.

[13] Fetzel, T., Niedertscheider, M., Haberl, H., Krausmann, F., Erb, K. H. (2016): Patterns and changes of land use and land-use efficiency in Africa 1980-2005: an analysis based on the human appropriation of net primary production framework. - Regional Environmental Change 16(5):1507-1520.

[14] Heute, A. R., Liu, H. Q., Batchily, K., Van Leeuwen, W. (1997): A comparison of vegetation indices over a global set of TM images for EOS-MODIS. - Remote Sensing of Environment, New York 59:440-451.

[15] Hilker, T., Lyapustin, A. I., Hall, F. G., Myneni, R., Knyazikhin, Y., Wang, Y., Tucker, C.J., Sellers, P. J. (2015): On the measurability of change in Amazon vegetation from MODIS. - Remote Sensing of Environment 166:233-242.

[16] Houborg, R., Soegaard, H., Boegh, E. (2007): Combining vegetation index and model inversion methods for the extraction of key vegetation biophysical parameters using Terra and Aqua MODIS reflectance data. - Remote Sensing of Environment 106(1):39-58.

[17] Jamali, S., Seaquist, J., Ardö, J., Eklundh, L. (2011): Investigating temporal relationships between rainfall, soil moisture and MODIS-derived NDVI and EVI for six sites in Africa. - Savanna 21(3):547-553.

[18] Jiang, Z., Huete, A. R., Didan, K., Miura, T. (2008): Development of a two-band enhanced vegetation index without a blue band. - Remote Sensing of Environment 112(10):3833-3845.

[19] Knezevic, M., Zivotic, L., Perovic, V., Topalovic, A., Todorovic, M. (2017): Impact of climate change on olive growth suitability, water requirements and yield in Montenegro. - Italian Journal of Agrometeorology-Rivista Italiana di Agrometeorologia 22(2):39-52.

[20] Liu, H. Q., Huete, A. (1995): A feedback based modification of the NDVI to minimize canopy background and atmospheric noise. - IEEE Transactions on Geoscience and Remote Sensing 33(2):457-465.

[21] Lorenz, R., Davin, E. L., Lawrence, D. M., Stöckli, R., Seneviratne, S. I. (2013): How important is vegetation phenology for European climate and heat waves? - Journal of Climate 26(24):10077-10100.

[22] Mao, D., Wang, Z., Li, L., Ma, W. (2014): Spatiotemporal dynamics of grassland aboveground net primary productivity and its association with climatic pattern and changes in Northern China. - Ecological Indicators 41:40-48.

[23] Moriondo, M., Bindi, M. (2007): Impact of climate change on the phenology of typical Mediterranean crops. - Italian Journal of Agrometeorology 3:5-12.

[24] Muhammad, S., Zhan, Y., Wang, L., Hao, P., Niu, Z. (2016): Major crops classification using time series MODIS EVI with adjacent years of ground reference data in the US state of Kansas. - Optik-International Journal for Light and Electron Optics 127(3):10711077.

[25] Mumtaz, R., Baig, S., Fatima, I. (2017): Analysis of meteorological variations on wheat yield and its estimation using remotely sensed data. A case study of selected districts of Punjab Province, Pakistan (2001-14). - Italian Journal of Agronomy 12(3). 
[26] Nagler, P. L., Cleverly, J., Glenn, E., Lampkin, D., Huete, A., Wan, Z. (2005): Predicting riparian evapotranspiration from MODIS vegetation indices and meteorological data. Remote Sensing of Environment 94(1):17-30.

[27] NASA MODIS Web: https://e4ft101.cr.usgs.gov/MOLA/MYD13A1.006/.

[28] Nouri, H., Glenn, E. P., Beecham, S., Chavoshi Boroujeni, S., Sutton, P., Alaghmand, S., Nagler, P. L., Noori, B. (2016): Comparing three approaches of evapotranspiration estimation in mixed urban vegetation: Field-based, remote sensing-based and observational-based methods. - Remote Sensing 8(6):492.

[29] Ogilvie, A., Belaud, G., Delenne, C., Bailly, J. S., Bader, J. C., Oleksiak, A., Ferry, L., Martin, D. (2015): Decadal monitoring of the Niger Inner Delta flood dynamics using MODIS optical data. - Journal of Hydrology 523:368-383.

[30] Peng, D., Wu, C., Li, C., Zhang, X., Liu, Z., Ye, H., Luo, Sh., Liu, X., Hu, Y., Fang, B. (2017): Spring green-up phenology products derived from MODIS NDVI and EVI: Inter comparison, interpretation and validation using National Phenology Network and AmeriFlux observations. - Ecological Indicators 77:323-336.

[31] Pisek, J., Rautiainen, M., Nikopensius, M., Raabe, K. (2015): Estimation of seasonal dynamics of understory NDVI in northern forests using MODIS BRDF data: Semiempirical versus physically-based approach. - Remote Sensing of Environment 163:4247.

[32] Potter, C., Boriah, S., Steinbach, M., Kumar, V., Klooster, S. (2008): Terrestrial vegetation dynamics and global climate controls in North America: 2001-05. - Earth Interactions 12(8):1-12.

[33] Raghavendra, B. R., Aslam, M. M. (2017): Sensitivity of vegetation indices of MODIS data for the monitoring of rice crops in Raichur district, Karnataka, India. - The Egyptian Journal of Remote Sensing and Space Science 20(2):187-195.

[34] Rahman, A. F., Sims, D. A., Cordova, V. D., El-Masri, B. Z. (2005): Potential of MODIS EVI and surface temperature for directly estimating per-pixel ecosystem C fluxes. Geophysical Research Letters 32(19).

[35] Ratana, P., Huete, A. R., Ferreira, L. (2005): Analysis of Cerrado physiognomies and conversion in the MODIS seasonal-temporal domain. - Earth Interactions 9(3):1-22.

[36] Shi, H., Li, L., Eamus, D., Huete, A., Cleverly, J., Tian, X., Yu, Q., Wang, Sh., Montagnani, L., Magliulo, V., Rotenberg, E. (2017): Assessing the ability of MODIS EVI to estimate terrestrial ecosystem gross primary production of multiple land cover types. Ecological Indicators 72:153-164.

[37] Sloan, S., Jenkins, C. N., Joppa, L. N., Gaveau, D. L., Laurance, W. F. (2014): Remaining natural vegetation in the global biodiversity hotspots. - Biological Conservation 177:12-24.

[38] Son, N. T., Chen, C. F., Chen, C. R., Minh, V. Q., Trung, N. H. (2014): A comparative analysis of multitemporal MODIS EVI and NDVI data for large-scale rice yield estimation. - Agricultural and Forest Meteorology 197:52-64.

[39] Spiekermann, R., Brandt, M., Samimi, C. (2015): Woody vegetation and land cover changes in the Sahel of Mali (1967-2011). - International Journal of Applied Earth Observation and Geoinformation 34:113-121.

[40] Testa, S., Soudani, K., Boschetti, L., Mondino, E. B. (2018): MODIS-derived EVI, NDVI and WDRVI time series to estimate phenological metrics in French deciduous forests. International Journal of Applied Earth Observation and Geoinformation 64:132-144.

[41] Tsalyuk, M., Kelly, M., Getz, W. M. (2017): Improving the prediction of African savanna vegetation variables using time series of MODIS products. - ISPRS Journal of Photogrammetry and Remote Sensing 131:77-91.

[42] Vermote, E. F., El Saleous, N. Z., Justice, C. O. (2002): Atmospheric correction of MODIS data in the visible to middle infrared: first results. - Remote Sensing of Environment 83(1-2):97-111. 
[43] Villani, G., Tomei, F., Tomozeiu, R., Marletto, V. (2011): Climatic scenarios and their impacts on irrigated agriculture in Emilia-Romagna, Italy. - Italian J. Agrometeorol. 1:516.

[44] Wang, X., Xie, H. (2009): New methods for studying the spatiotemporal variation of snow cover based on combination products of MODIS Terra and Aqua. - Journal of Hydrology 371(1-4):192-200.

[45] Wardlow, B. D., Egbert, S. L., Kastens, J. H. (2007): Analysis of time-series MODIS 250 $m$ vegetation index data for crop classification in the US Central Great Plains. - Remote Sensing of Environment 108(3):290-310.

[46] Waring, R. H., Coops, N. C., Fan, W., Nightingale, J. M. (2006): MODIS enhanced vegetation index predicts tree species richness across forested ecoregions in the contiguous USA. - Remote Sensing of Environment 103(2):218-226.

[47] Yang, J., Chen, H., Borjigin, N., Zhao, M., Zhou, Y., Huang, Y. (2017): Validation of the MODIS LAI product in Qinghai Lake Basin combined with field measurements using Landsat 8 OLI data. - Acta Ecologica Sinica 37(5):322-331.

[48] Zhang, B., Zhang, L., Xie, D., Yin, X., Liu, C., Liu, G. (2015): Application of synthetic NDVI time series blended from Landsat and MODIS data for grassland biomass estimation. - Remote Sensing 8(1):10.

[49] Zhang, J., Zhang, L., Xu, C., Liu, W., Qi, Y., Wo, X. (2014): Vegetation variation of mid-subtropical forest based on MODIS NDVI data. - A case study of Jinggangshan City, Jiangxi Province. - Acta Ecologica Sinica 34(1):7-12.

[50] Zhang, Q., Cheng, Y. B., Lyapustin, A. I., Wang, Y., Xiao, X., Suyker, A., ... Middleton, E. M. (2014): Estimation of crop gross primary production (GPP): I. impact of MODIS observation footprint and impact of vegetation BRDF characteristics. - Agricultural and Forest Meteorology 191:51-63.

[51] Zhang, X., Friedl, M. A., Schaaf, C. B., Strahler, A. H., Hodges, J. C., Gao, F., ... Huete, A. (2003): Monitoring vegetation phenology using MODIS. - Remote Sensing of Environment 84(3):471-475.

[52] Zheng, X., Eltahir, E. A. (1998): The role of vegetation in the dynamics of West African monsoons. - Journal of Climate 11(8):2078-2096.

[53] Zhou, Y., Xiao, X., Qin, Y., Dong, J., Zhang, G., Kou, W., Jin, C., Wang, J., Li, X. (2016): Mapping paddy rice planting area in rice-wetland coexistent areas through analysis of Landsat 8 OLI and MODIS images. - International Journal of Applied Earth Observation and Geoinformation 46:1-12. 